\title{
Risk Factors of Childhood Diarrhoeal Diseases in Bangladesh: Evidence from a Nationwide Cross-sectional Survey
}

Siddiqi, N.A.MD., Muyeed, A. (2021). Risk factors of childhood diarrhoeal diseases in Bangladesh: Evidence from a nationwide cross-sectional survey. Journal of Health Systems and Policies (JHESP), 3,97-109

MD. Nure Alam SIDDIQI ${ }^{*}$

\section{Abdul MUYEED ${ }^{2}$}

\begin{abstract}
Globally, different episodes of diarrhoeal diseases are one of the leading causes of childhood morbidity and mortality, especially in developing countries. Diarrhoeal diseases among children under five years of age have been considered as the major causes of morbidity and mortality in Bangladesh although it has declined recently. In this study, the most recently published Multiple Indicator Cluster Survey 2019 (MICS 2019) data were used to observe the prevalence of childhood diarrhoea and to identify the socio-economic and demographic risk factors of childhood diarrhoea in Bangladesh. The chi-square test was used in this study to identify the risk factors of childhood diarrhoeal diseases in Bangladesh. The overall prevalence of diarrhoea among children under five years of age in Bangladesh was found $6.9 \%$ in the last
\end{abstract}

\footnotetext{
${ }^{1}$ Department of Population Science, Jatiya Kabi Kazi Nazrul Islam University, Trishal, Mymensingh, Bangladesh ${ }^{2}$ Department of Statistics, Jatiya Kabi Kazi Nazrul Islam University, Trishal, Mymensingh, Bangladesh

${ }^{*}$ Corresponding author: MD. N. A. SIDDIQI, nurealam rasel@yahoo.com
} 
two weeks preceding the survey. The findings of the study identified that child age less than two years, an unimproved facility of toilet or source of drinking water, floor material made of earth/sand, no handwashing place observed in dwelling/ yard/plot, lower or no education of mothers and household heads, lower economic status, three or more under-five children living in the family are the most potential risk factors of childhood diarrhea in Bangladesh. Improved source of drinking water supply, better sanitation, hygiene practice, mother's knowledge and consciousness about diarrhoea and, timely treatment and can reduce the burden of childhood diarrhoea in Bangladesh. The quality of existing child healthcare services like oral rehydration therapy (ORT) during diarrhoea, rotavirus vaccination programs should be improved at all stages without any discrimination which will contribute to a reduction in childhood morbidity and mortality due to diarrhoea in Bangladesh.

Keywords: Childhood Diarrhoea, Risk Factors, Multiple Indicator Cluster Survey (MICS), Bangladesh

\section{INTRODUCTION}

Globally, different episodes of diarrhoeal diseases are one of the leading causes of childhood morbidity and mortality, especially in developing countries (Moharana et al., 2019; Peter and Umar, 2018; Sanyaolu et al., 2020), killing nearly 1.5 million children annually (Sarker, 2016). Diarrhoea is the condition showing the frequent and excessive discharge of or loose stools from the bowel. Although deaths due to diarrhoea has been declined globally (Ahmed et al., 2018), it still remains the second major causes of deaths among under-five children (Workie et al., 2018), and according to the World Health Organization, there are nearly 1.7 billion cases of diarrhoea occurred every year worldwide among children under five (Sarker, 2016; Peter and Umar, 2018; WHO, 2017). A recent report by the International Vaccine Access Center (IVAC), Johns Hopkins Bloomberg School of Public Health reveals that about 1200 young children die due to diarrhoea every day which means that it claimed the lives of 
approximately 4,37,000 children per year (Pneumonia and Diarrhea Progress Report 2020). Besides mortality, the longer duration of diarrhoea among children is a major threat to child health (Li et al., 2020) that have a greater adverse effect on nutritional status of children and child loses the nutrition during each episode of diarrhoea which is essential for the growth of the children (Alemayehu et al., 2020). Diarrhoea lasts up to several days is responsible for removing essential body fluids and vital nutrients necessary for normal body functions causing severe dehydration which is the main cause of death among children suffering from diarrhoea (Sanyaolu et al., 2020). Diarrhoea among newborns and infants is more dangerous, leading to dehydration in just one or two days. A child suffering from dehydration can die within a very few days. Diarrhoea is associated with a high rate of malnutrition through nutrient loss, reduced food appetite, and mal-absorption and energy intake which in turn causes immune deficiency and increased susceptibility to infections like contracting diarrhoea again (Wasihun et al., 2018). The etiological factors responsible for causing diarrhoea or pathogens of diarrhoea transmitted from infected to susceptible people through one or more of the environmental reservoirs such as food, water, fields, fingers, flies, etc. by human-environment interaction or by natural processes (Julian, 2016). Many germs such as bacteria, parasites, fungi, or viruses can cause infections that lead to diarrhoea. Rotavirus has been reported to be the most common cause of severe childhood diarrhoea both in developed and developing countries (Nirwati et al., 2016).

Diarrhoea is a major public health problem in Bangladesh and the most challenging issue for health which remains one of the major causes of morbidity and mortality, especially in children under five years of age. Diarrhoeal diseases among children less than five years in Bangladesh have been considered as the major causes of mortality (Islam, 2020), but have declined recently (Billah et al., 2019). Two or three decades ago, one-third of the total child death burden in Bangladesh was due to diarrhoea (Victora et al., 1993) which was responsible 
for $15 \%-30 \%$ of deaths among the under-five children of Bangladesh (Piechulek et al., 2003). But the recent Bangladesh Demographic and Health Survey (BDHS) 2017-18 reported that only $3.2 \%$ of under-five children deaths occurred due to diarrhoea and the death rate was highest among the postneonatal age group that is between 1-11 months (14.1\%) (NIPORT and ICF, 2020). Many types of research have been conducted about the prevalence and risk factors of childhood diarrhoea using nationally representative survey, but in this study, we have used the most recent published Multiple Indicator Cluster Survey 2019 (MICS 2019) data to identify the prevalence of childhood diarrhoea and examine the risk factors of diarrhoea with different demographic and socio-economic factors in Bangladesh.

\section{METHODOLOGY}

In this study, data were extracted from the population-based cross-sectional survey (UNICEF, 2019) from the Multiple Indicator Cluster Survey (MICS) Bangladesh 2019, which was done by the Bangladesh Bureau of Statistics (BBS) in collaboration with the United Nations Children's Fund (UNICEF) Bangladesh, as part of the Global MICS Program. It is the sixth round of this kind of survey (MICS6) in Bangladesh. The UNICEF provides the technical support for this survey and the United Nations Population Fund (UNFPA) Bangladesh also provided the financial resource to undertake quality assurance visits during data collection. The MICS6 used a standard set of questionnaires designed to collect nationally representative data on statistically reliable estimates of demographic, health, and nutrition indicators of children and women for rural, urban, and national levels. Using a two-stage stratified cluster sampling, the primary sampling units (PSUs) selected at the first stage and a sample ofhouseholds were selected at the second stage. The number PSU and number of sampled households in this survey were selected 3,220 and 64,400 respectively. In MICS6, mothers or caretakers were asked whether their child under age five years had an episode of diarrhoea in the two weeks before the survey which is considered as the dependent variable for this study. A sub-sample of 23,069 
children for whom mothers reported that the child had diarrhoea (excluding missing values concerning dependent and explanatory variables) aged between 0-59 months were selected for this study.

The ethical consideration and protocol of this survey were approved by the technical committee of the Government of Bangladesh lead by the Bangladesh Bureau of Statistics (BBS). Consent about the interview and questionnaire was obtained for each respondent who participated in the survey. Details about the sampling design, standard questionnaire, and data collection procedure are available in the final report of 2019 MICS (Bangladesh Bureau of Statistics and UNICEF Bangladesh, 2019).

In this study, some socio-economic and demographic risk factors are assessed as independent or explanatory variables which are child's age, sex of child, type of toilet facility, source of drinking water, place where household members most often wash their hands, type of floor material, educational qualification of the mother, educational status of household head, number of under-five children in the family, wealth index, area of residence and place of administrative division.

Data and statistical analyses in this study were performed using the IBM SPSS for Windows ver. 23.0 (IBM Corp., Armonk, NY, USA). Descriptive statistical analysis was performed to characterize the study population concerning explanatory variables. The chisquare $(\chi 2)$ test is an important non-parametric test that is simply a technique to test either as a test of goodness of fit or as a test to judge the significance of the association between attributes. In this study, chi-square $\left(\chi^{2}\right)$ test is performed to identify the socio-economic and demographic risk factors associated with diarrhoea among under-five children in Bangladesh.

\section{RESULTS}

The overall prevalence of diarrhoea among children under five years of age in Bangladesh was found $6.9 \%$ in the last two weeks preceding the survey (Table 1). The highest 
percentage of reported diarrhoea was found among the child age group 12-23 months $(10.2 \%)$ and after that, the prevalence decreases with the increase of age and found lowest among the child age group 48-59 months (3.4\%). In this study, boys (7.1\%) were found more affected by childhood diarrhoea than those of girls children (6.6\%). We observed in this study that improved sanitation, improved source of drinking water, and available handwashing facility decreases the chance of having diarrhoeal diseases among children. The percentage of children having diarrhoea among the household with improved toilet facilities, improved sources of drinking water, and observed facility of handwashing facility were $6.4,6.8$, and 6.3 respectively. On the other hand, this percentage among the household with unimproved toilet facility, unimproved source of drinking water and with not observed availability of handwashing facility were 9.2, 10.3, and 9.6 respectively. The diarrhoeal diseases among under-five children were more prevalent among the house living with floor material earth/sand (7.4\%) compared to floor material cement/carpet/tiles (5.9\%) and others (6.2\%). The secondary educated mothers $(6.7 \%)$ and higher secondary/higher educated mothers $(5.7 \%)$ experienced a lower prevalence of childhood diarrhoea than mothers with pre-primary/no education $(7.7 \%)$ and primary education (7.6\%) respectively. A similar pattern was found about the educational status of the household head with a higher prevalence of childhood diarrhoea found among lower educated household head compared to educated counterpart. The family with 2 or fewer under-five children $(6.6 \%)$ experienced a lower prevalence of childhood diarrhoea than a family having 3 or more underfive children $(8.2 \%)$. The percentage of under-five children affected by episodes of diarrhoea prior to the last week of the survey was found $8.5 \%, 7.9 \%, 5.9 \%, 6.2 \%$, and $5.1 \%$ respectively among the household with wealth index poorest, poor, middle, fourth, and richest respectively. Our studies found no variation in the prevalence of diarrhoea among under-five children of Bangladesh living in rural and urban areas, but diarrhoeal disease was found greatly varied by 
the geographic division of the country with the highest prevalence in Barishal (12.4\%) and lowest prevalence was reported in Rangpur (4.2\%).

The result of the chi-square $\left(\chi^{2}\right)$ test of Table 1 also shows that there is a statistically significant association exist between the prevalence of childhood diarrhoea and different socioeconomic and demographic factors such as child's age, type of toilet facility, source of drinking water, place where household members most often wash their hands, type of floor material, educational qualification of the mother, educational status of household head, number of underfive children in the family, wealth index, place of administrative division. Out of all the explanatory variables, the sex of children and area of residence of the children shows a statistically insignificant association with the prevalence of childhood diarrhoea.

Table 1: Prevalence of diarrhoea and its associated risk factors among under-five children in Bangladesh

\begin{tabular}{|c|c|c|c|c|}
\hline $\begin{array}{l}\text { Socio-economic and } \\
\text { demographic factors }\end{array}$ & $\begin{array}{c}\text { Total } \\
\text { Children }\end{array}$ & $\begin{array}{l}\text { Number of children } \\
\text { who had an episode of } \\
\text { diarrhoea in the last } \\
\text { two weeks of the } \\
\text { survey (Percentage) }\end{array}$ & $\begin{array}{l}\text { Chi- } \\
\text { square } \\
\text { value }\end{array}$ & P-value \\
\hline $\begin{array}{l}\text { Child age } \\
0-11 \\
12-23 \\
24-35 \\
36-47 \\
48-59 \\
\end{array}$ & $\begin{array}{l}4540 \\
4512 \\
4590 \\
4785 \\
4642\end{array}$ & $\begin{array}{c}408(9.0) \\
459(10.2) \\
328(7.1) \\
231(4.8) \\
157(3.4)\end{array}$ & 228.977 & $<0.001 * * *$ \\
\hline $\begin{array}{l}\text { Sex of child } \\
\text { Male } \\
\text { Female }\end{array}$ & $\begin{array}{l}11937 \\
11132 \\
\end{array}$ & $\begin{array}{l}847(7.1) \\
136(6.6)\end{array}$ & 2.111 & 0.146 \\
\hline $\begin{array}{l}\text { Type of toilet facility } \\
\text { Improved }^{1} \\
\text { Not Improved }^{2}\end{array}$ & $\begin{array}{c}18948 \\
4121\end{array}$ & $\begin{array}{c}1204(6.4) \\
379(9.2)\end{array}$ & 42.794 & $<0.001 * * *$ \\
\hline $\begin{array}{l}\text { Source of drinking } \\
\text { water } \\
\text { Improved }^{3} \\
\text { Not Improved } \\
\end{array}$ & $\begin{array}{c}22513 \\
556\end{array}$ & $\begin{array}{c}1526(6.8) \\
57(10.3)\end{array}$ & 10.243 & $0.001 * * *$ \\
\hline $\begin{array}{l}\text { Fixed hand washing } \\
\text { facility like tube } \\
\text { well/tap/sink in the } \\
\text { dwelling/yard/plot } \\
\text { Observed }^{5} \\
\text { Not Observed }^{6}\end{array}$ & $\begin{array}{c}19378 \\
3691\end{array}$ & $\begin{array}{l}1230(6.3) \\
353(9.6)\end{array}$ & 50.186 & $<0.001 * * *$ \\
\hline
\end{tabular}




\begin{tabular}{|c|c|c|c|c|}
\hline $\begin{array}{l}\text { Type of floor material } \\
\text { Earth or Sand } \\
\text { Cement/Tiles/Carpets } \\
\text { Others }{ }^{7}\end{array}$ & $\begin{array}{c}14784 \\
6880 \\
1405 \\
\end{array}$ & $\begin{array}{c}1091(7.4) \\
405(5.9) \\
87(6.2) \\
\end{array}$ & 17.425 & $<0.001 * * *$ \\
\hline $\begin{array}{l}\text { Educational status of } \\
\text { mother } \\
\text { Pre-primary or no } \\
\text { education } \\
\text { Primary } \\
\text { Secondary } \\
\text { Higher secondary or } \\
\text { higher }\end{array}$ & $\begin{array}{c}2590 \\
5552 \\
11348 \\
3579\end{array}$ & $\begin{array}{l}199(7.7) \\
423(7.6) \\
757(6.7) \\
204(5.7)\end{array}$ & 15.922 & $0.001 * * *$ \\
\hline $\begin{array}{l}\text { Educational status of } \\
\text { household head } \\
\text { Pre-primary or no } \\
\text { education } \\
\text { Primary } \\
\text { Secondary } \\
\text { Higher secondary or } \\
\text { higher }\end{array}$ & $\begin{array}{l}6918 \\
6957 \\
6431 \\
2763\end{array}$ & $\begin{array}{l}494(7.1) \\
524(7.5) \\
420(6.5) \\
145(5.2)\end{array}$ & 18.094 & $<0.001 * * *$ \\
\hline $\begin{array}{l}\text { Number of under-five } \\
\text { children in the family } \\
2 \text { or less } \\
3 \text { or more }\end{array}$ & $\begin{array}{c}19637 \\
3432\end{array}$ & $\begin{array}{c}1303(6.6) \\
280(8.2)\end{array}$ & 10.604 & $0.001 * * *$ \\
\hline $\begin{array}{l}\text { Wealth index } \\
\text { Poorest } \\
\text { Second } \\
\text { Middle } \\
\text { Fourth } \\
\text { Richest }\end{array}$ & $\begin{array}{l}5746 \\
4828 \\
4350 \\
4306 \\
3839\end{array}$ & $\begin{array}{l}487(8.5) \\
378(7.8) \\
256(5.9) \\
267(6.2) \\
195(5.1)\end{array}$ & 59.003 & $<0.001 * * *$ \\
\hline $\begin{array}{l}\text { Area of residence } \\
\text { Urban } \\
\text { Rural }\end{array}$ & $\begin{array}{c}4296 \\
18773 \\
\end{array}$ & $\begin{array}{c}295(6.9) \\
1288(6.9)\end{array}$ & 0.000 & 0.989 \\
\hline $\begin{array}{l}\text { Place of administrative } \\
\text { division } \\
\text { Barishal } \\
\text { Chattogram } \\
\text { Dhaka } \\
\text { Khulna } \\
\text { Mymensingh } \\
\text { Rajshahi } \\
\text { Rangpur } \\
\text { Sylhet }\end{array}$ & $\begin{array}{l}2052 \\
4801 \\
4508 \\
3173 \\
1387 \\
2404 \\
2768 \\
1976 \\
\end{array}$ & $\begin{array}{l}254(12.4) \\
385(8.0) \\
249(5.5) \\
203(6.4) \\
112(8.1) \\
152(6.3) \\
116(4.2) \\
112(5.7) \\
\end{array}$ & 161.059 & $<0.001 * * *$ \\
\hline Total & 23069 & $1583(6.9)$ & & \\
\hline $\begin{array}{l}\text { Note: } \\
{ }^{* * *} \text { Significant at } \mathrm{p}<0.01, \\
{ }^{1} \text { Improved toilet includes: flu } \\
\text { Pit latrine with slab, Compost } \\
{ }^{2} \text { Unimproved latrine include } \\
\text { defecation (no facility or bush, }\end{array}$ & $\begin{array}{l}\text { ur flush to } \\
\text { let, } \\
\text { en drain, }\end{array}$ & $\begin{array}{l}\text { istem, se } \\
\text { thout slat }\end{array}$ & trine, & $\begin{array}{l}\text { d pit latrine, } \\
\text { atrine, Other }\end{array}$ \\
\hline
\end{tabular}


${ }^{3}$ Improved source of drinking water includes: Piped water- into dwelling, into yard/plot, to neighbour, public tap/standpipe, Tubewell/borne hole, Protected well, Protected spring, Rainwater collection, Cart with a small tank, Water kiosk, Bottled water, Sachet water.

${ }^{4}$ Unimproved source of drinking water includes: Unprotected well, Unprotected spring, Surface water, other

${ }^{5}$ Observed Place where household members most often wash their hands includes fixed facility observed in (sink/tap/tubewell) in dwelling, (sink/tap/tubewell) in yard/plot, mobile object includes bucket, jug kettle.

${ }^{6}$ Not Observed Place where household members most often wash their hands includes: No handwashing place in dwelling/yard/plot, no permission to see, other reason.

${ }^{7}$ Others include dung, wood planks, palm/ bamboo/ betel nut, parquet or polished wood, vinyl, or asphalt strips.

\section{DISCUSSIONS AND CONCLUSIONS}

Bangladesh has achieved much improvement in child health status and reducing the burden of childhood diseases which reflects in this study that the prevalence of childhood diarrhoea is only $6.9 \%$ which was much more in two or three decades ago. Some socioeconomic and demographic factors have been identified as potential risk factors of childhood diarrhoea in this study. The association between a child's age and the prevalence of diarrhoea was found highly significant in the present study. As the age of the child increases, the prevalence of diarrheal diseases falls. After one year of age, a child begins to walk alone successfully and for this reason, their risk of exposure to contaminated agents and various types of infections from the environment increases at the age of 12-23 months but again with the increase of age the risk of having diarrhoea decreased. Similar results have been found by Sarker et al., 2016 in Bangladesh. It is widely recognized that the source of drinking water and type of toilet facility are the most important sanitation variables that are closely associated with diarrhoeal morbidity and mortality. The disease agents can easily be transmitted to a new host if the toilet used by the house is not safe enough. The human excreta contain various fecalborne disease agents which can be transmitted to a new host through various channels such as water, fingers, flies, soil, and foods. Diarrhoea can also be transmitted by both water-borne and water-washed mechanisms. Inadequate, improper, and unsafe water supplies are closely associated with the high prevalence of childhood diarrhoea in Bangladesh. In this study, the diarrhoeal prevalence among children was found among the children living in the household 
who have unimproved toilet facility and unimproved source of drinking water which are significantly associated with childhood diarrhoea in Bangladesh and considered as the potential risk factors. This finding is consistent with those of other many studies in Bangladesh and also other countries for example a study in Ghana by Boadi and Kuitunen (2005). A study by Hashi, 2017 reveals that handwashing with soap practice reduces an overall diarrhoeal diseases reduction by $35 \%$. Our study findings show that the household where there was no permanent facility for handwashing was observed at the time of the survey were experienced a higher prevalence of childhood diarrhoea compared to their counterparts. Since the floor made of dirt materials cannot be washed they are more likely to provide a breeding ground for various agents that are responsible for causing diarrhoea and among children. The diarrhoeal prevalence is observed significantly related with floor material of house and it is more prevalent among the children from the house whose floor materials are made from earth or sand and the result is an agreement with the study result by Sarker et al., 2016 and Workie et al., 2019.

Parental knowledge and understanding are very much essential for reducing the burden of childhood diarrhoea. Educated mother and father can have better knowledge about domestic hygiene which contributes to the lower prevalence of diarrhoea. The low educational status of the mother and household head are identified as important risk factors of childhood diarrhoea in this study. In this study, education of mother and education of household head is found a highly significant association with suffering different episodes of diarrhoea two weeks preceding the survey, and these findings also consistent with many national and international studies such as a study done by Mihrshahi et al., 2007. The family where three or more underfive children lives experienced a high prevalence of diarrhoeal disease than a family with two or fewer under-five children. Dessalegn et al., 2011 and Siziya, 2009 found in their study that the prevalence of diarrhoea among children was low among rich families compared to the poor family, our study findings also consistent with these findings. The economic status of a 
household is an indicator of access to adequate food supplies, use of health services, availability of improved water sources and sanitation facilities, which decreases the chance of having childhood diarrhoea. The current study founds no variation in the diarrhoeal prevalence of children in rural areas but observed a great variation in occurring childhood diarrhoea in the different divisions of the country.

Although among the children under five years of age in Bangladesh is a major public health problem but these problems can be reduced with access to simple, affordable interventions like oral rehydration therapy (ORT) during diarrhoea. Improved source of drinking water supply, better sanitation, hygiene practice, timely treatment can reduce the burden of childhood diarrhoea in Bangladesh. People should be encouraged to make hygienic toilets at their homes and use safe water for drinking purposes. An educated parent would make better use of medical facilities for their children that will contribute to a reduction in childhood morbidity and mortality due to diarrhoea. So community-based educational programs should be strengthened. The findings of the study suggest that the use of oral rehydration therapy should be increased when a child suffered from diarrhoea and parents should take medical treatment immediately for their children suffered from diarrhoea, parents should also be conscious about the rotavirus vaccination program in the country. Efforts should be made to improve the quality of existing child healthcare services and ensure adequate access to child healthcare facilities at all stages without any discrimination.

\section{REFERENCES}

Ahmed, M., Abedin, J., Alam, K. F., Al Mamun, A., Paul, R. C., Rahman, M., Luliano, A. D., Sturm Ramirez, K., Parashar, U., Luby, S. P., Gurley, E. S. (2018). Incidence of acute diarrhea-associated death among children $<5$ years of age in Bangladesh, 2010-12. The American Journal of Tropical Medicine and Hygiene, 98,281-286.

Alemayehu, M., Alemu, T., Astatkie, A. (2020). Prevalence and determinants of diarrhea among under-five children in Benna Tsemay District, South Omo Zone, Southern Ethiopia: A community-based cross-sectional study in pastoralist and agropastoralist context. Advances in Public Health. 
Billah, S. M., Raihana, S., Ali, N. B., Iqbal, A., Rahman, M. M., Khan, A. N. S., Karim, F., Karım, M. A., Hasan, A., Jackson, B., Walker, N., Hossain, M. A., Sarker, S., Black, R. E., El Arifeen, S. (2019). Bangladesh: A success case in combating childhood diarrhoea. Journal of Global Health, 9,20803.

Boadi, K. O., Kuitunen, M. (2005). Childhood diarrheal morbidity in the Accra Metropolitan Area, Ghana: Socioeconomic, environmental and behavioral risk determinants. Journal of Health and Population in Developing Countries, 7,15-22.

Dessalegn, M., Kumie, A., Tefera, W. (2011). Predictors of under-five childhood diarrhea: Mecha District, West Gojam, Ethiopia. Ethiopian Journal of Health Development, 25,192-200.

Hashi, A., Kumie, A., Gasana, J. (2017). Hand washing with soap and WASH educational intervention reduces under-five childhood diarrhoea incidence in Jigjiga District, Eastern Ethiopia: A community-based cluster randomized controlled trial. Preventive Medicine Reports, 6,361-368.

Islam, M. R., Nuzhat, S., Fahim, S. M., Palit, P., Flannery, R. L., Kyle, D. J., Mahfuz, M., Islam, M. M., Sarker, S. A., Ahmed, T. (2020). Antibiotic exposure among young infants suffering from diarrhoea in Bangladesh. Journal of Paediatrics and Child Health. 57,395-402.

Johns Hopkins Bloomberg School of Public Health, International Vaccine Access Center. (2020). Pneumonia and Diarrhea Progress Report 2020. https://www.jhsph.edu/ivac/resources/pdpr/

Julian, T. R. (2016). Environmental transmission of diarrheal pathogens in low and middle income countries. Environmental Science: Processes and Impacts, 18,944-955.

Li, R., Lai, Y., Feng, C., Dev, R., Wang, Y., Hao, Y. (2020). Diarrhea in under five year-old children in Nepal: A spatiotemporal analysis based on demographic and health survey data. International Journal of Environmental Research and Public Health, 17,2140.

Mihrshahi, S., Ichikawa, N., Shuaib, M., Oddy, W., Ampon, R., Dibley, M. J., Kabir, A. K. M. I., Peat, J. K. (2007). Prevalence of exclusive breastfeeding in Bangladesh and its association with diarrhoea and acute respiratory infection: Results of the multiple indicator cluster survey 2003. Journal of Health, Population, and Nutrition, 25,195-204.

Moharana, S. S., Panda, R. K., Dash, M., Chayani, N., Bokade, P., Pati, S., Bhattacharya, D. (2019). Etiology of childhood diarrhoea among under five children and molecular analysis of antibiotic resistance in isolated enteric bacterial pathogens from a tertiary care hospital, Eastern Odisha, India. BMC Infectious Diseases, 19,1-9.

National Institute of Population Research and Training and ICF. (2020). Bangladesh Demographic and Health Survey 2017-18. https://dhsprogram.com/pubs/pdf/FR344/FR344.pdf

Nirwati, H., Wibawa, T., Aman, A. T., Wahab, A., Soenarto, Y. (2016). Detection of group a rotavirus strains circulating among children with acute diarrhea in Indonesia. Springerplus, 5,1-6.

Peter, A. K., Umar, U. (2018). Combating diarrhoea in Nigeria: The way forward. Journal of Microbiology and Experimentation, 6,191-197.

Piechulek, H., Al-Sabbir, A., Mendoza-Aldana, J. (2003). Diarrhea and ARI in rural areas of Bangladesh. Southeast Asian Journal of Tropical Medicine and Public Health, 34,337-342.

Sanyaolu, A., Okorie, C., Marinkovic, A., Jaferi, U., Prakash, S., Jan, A., Mangat, J. (2020). Global epidemiology and management of acute diarrhea in children from developing countries. Annals of Pediatrics and Child Health, 8,1205 .

Sarker, A. R., Sultana, M., Mahumud, R. A., Sheikh, N., Van Der Meer, R., Morton, A. (2016). Prevalence and health care-seeking behavior for childhood diarrheal disease in Bangladesh. Global Pediatric Health, 3,1-12.

Siziya, S., Muula, A. S., Rudatsikira, E. (2009). Diarrhoea and acute respiratory infections prevalence and risk factors among under-five children in Iraq in 2000. Italian Journal of Pediatrics, 35,1-9. 
UNICEF Bangladesh Bureau of Statistics (2019). Progotir Pathey Bangladesh, Multiple Indicator Cluster Survey. https://www.unicef.org/bangladesh/media/3281/file/Bangladesh\%202019\%20MICS\%20Report_English.pdf

United Nations Children's Fund. (2019). The Bangladesh Multiple Indicator Cluster Survey 2019. https://mics.unicef.org/surveys

Victora, C. G., Huttly S. R., Fuchs, S. C., Barros, F. C., Garnne, M., Leroy, O., Fontaine, O., Beau, J. P., Fauveau, V., Chowdhury, H. R., Yunus, M., Chakraborty, J., Sarder, A. M., Kapoor, S. K., Bhan, M. K., Nath, L. M., Martines, J. C. (1993). International differences in clinical patterns of diarrheal deaths: A comparison of children from Brazil, Senegal, Bangladesh, and India. Journal of Diarrhoeal Diseases Research, 11,25-29.

Wasihun, A. G., Dejene, T. A., Teferi, M., Marugán, J., Negash, L., Yemane, D., McGuigan, K. G. (2018). Risk factors for diarrhoea and malnutrition among children under the age of 5 years in the Tigray Region of Northern Ethiopia, PLoS One, 13,e0207743.

Workie, G. Y., Akalu, T. Y., Baraki, A. G. (2019). Environmental factors affecting childhood diarrheal disease among under-five children in Jamma district, South Wello zone, Northeast Ethiopia. BMC Infectious Diseases, 19,1-7.

Workie, H. M., Sharifabdilahi, A. S., Addis, E. M. (2018). Mothers' knowledge, attitude and practice towards the prevention and home-based management of diarrheal disease among under-five children in Diredawa, Eastern Ethiopia, 2016: A cross-sectional study. BMC Pediatrics, 18,1-9.

World Health Organization (2017). https://www.who.int/news-room/fact-sheets/detail/diarrhoealdisease\#: :text=A\%20significant $\% 20$ proportion $\% 20 \mathrm{of} \% 20$ diarrhoeal,children $\% 20$ under $\% 20 \mathrm{five} \% 20 \mathrm{years} \% 20 \mathrm{o}$ ld. 